\title{
Stereoscopic Perception of Flow Velocity Using Anaglyphic Technique
}

\author{
アナグリフィック・ステレオグラムの手法を使った流速分布の立体知覚
}

Masayuki UENO, Shin-ichi OKUMURA and Masayuki YAMAZAKI

Department of Electro-photo-optics, Faculty of Engineerig, Tokai

University 1117 Kitakaname, Hiratsuka, Kanagawa, 259-12 Japan

( Accepted for publication 18 Nobember 1993)

\section{1.はじめに}

流れの観測方法の一つに流速分布を立体 感に変えて観察する方法（カメロン効果 ' ) がある。裸眼でこれが見られるようになる には練習がいる。この負担在軽くするため にアナグリフィック・ステレオグラム゙の 助けを借りた。

\section{2. 方法"}

流れ（に浮かべた指標）の映像を適当な 時間間隔でフレームメモリ（A画面とB画 面）に取り込む。A画面に取り込んだ映像 を T Vモニタに再生し、それを青色フィル 夕を通してカラーフィルムで撮影する。次 ぎに、B画面に取り込んだ映像を T V モ二 夕に再生し、それを赤色フィル夕を通して $\mathrm{A}$ 画面の映像を撮影したのと同じフィルム 駒上に撮影する

（2 重露光する）。力ラ一印画紙に瑨き付 けた後、それを赤青眼鏡越しに眺める。

\section{3. 結果}

黒汁を混ぜた水にアルミニウムの微粉末 を指標しして浮か心゙、適当な容器に入れて 流した。 円形容器内の回転水流とC型チャ ンネル内の直進水流を撮影した結果をそれ ぞれ P hot o. 1 と P hoto. 2 に示 す。これらの写真は編集の都合でモノクロ になっているが、本来はカラ一写真である。 これらの写真で薄い部分が赤色を，濃い部 分が青色を表している。赤青眼鏡を掛けて 本来のカラー写真を眺めると、それぞれの 流れの流速分布に対応した立体感が生じる. $\mathrm{Ph}$ o t o g r a p h y 1 の例では、平面 の写真がうねって見える。 Photo g r a p h y. 20例ではU字型排水溝を真上 から見下ろしたときに似た凹凸感覚が生じ る。（凹凸感は眼鏡の掛け方によって反転 する。）
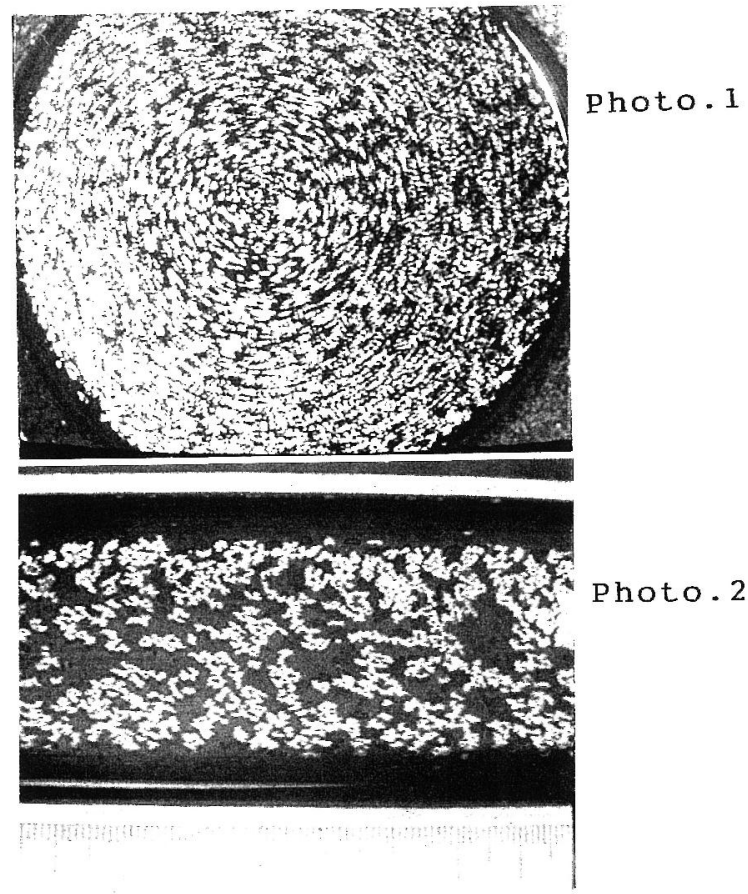

4.おわりに

アナグリフィック・ステレオグラムの手 法をとりいれることによってカメロン効果 がより簡単に観察できるようになった。人 間の視覚能力をたよりにするこの観察方法 は流速を定量的に測るには向いていないが、 流れの全体の様子が一覧できるので、詳細 に测定、解析すべき領域を特定するのに役 立つ。

参考文献

1 H. L. Cameron:Photogrammetric Eng. 99 (1952)

2 応用物理学会光学懇話会編「生理光学」 朝倉書店 (1975)第7 章.

*赤フィル夕、青フィル夕を装着したスト ロボライトを適当な時間間隔で発光させ、 それを使って流れを撮影しても良い。

93 SAS Intelligent Symposium

(C) 1993 Society of Advanced Science 